\title{
Phosphorus Removal of Urban Wastewater by Physico- Chemical Treatment: Waterways Euthrophication Prevention
}

\author{
Nawel Nedjah, Oualid Hamdaoui, and Nabila Laskri
}

\begin{abstract}
The most important nutrients in controlling water quality are: carbon, nitrogen and phosphorus. They are essential to the growth of all living organisms. These are the nutritional pillars of bacteria, fish, trees and humans.

Unfortunately, when a water body or plan becomes rich in these nutrients, particularly phosphorus, this causes some organisms such as algae to grow in abundance which makes the environment ugly. These algae are usually undesirable and may inevitably cause changes in $\mathrm{pH}$, dissolved oxygen, colour and turbidity of the water environment, hence the environment becomes eutrophic and its color turns to green.

To address and solve the eutrophication issue, the amount of phosphorus discharged into the receiving milieu must be reduced; and this constitutes the main purpose of our research.

We proceeded so as to make a physico-chemical phosphorus removal from urban waste water. The physico-chemical treatment is based on looking for and finding the optimal dose of the various added coagulants.

The aim of our work is to confirm the efficiency of the chemical treatment through use: lime, ferric chloride and aluminum sulfate as coagulant for this treatment.
\end{abstract}

Index Terms-Nutrient, phosphorus, algae, eutrophication, coagulant.

\section{INTRODUCTION}

The excessive intake in the natural environment of nitrogen and phosphate load in wastewater, from agricultural activities, domestic and industrial pollution, represents a pollution threat and a serious danger to the aquatic environment.

Our main objective is to eliminate the maximum existing phosphorus in wastewater by the chemical treatment, which can actually eliminate almost total phosphorus.

Municipal waste water contains various wastes, and usually consists of about $99.94 \%$ liquid and $0.06 \%$ solids. If this wastewater is not treated or improperly collected, it can affect both public health and environment [1].

The main objective of a treatment plant wastewater is to purify the water while reducing the concentration of solids, organic matter, nutrients, bacteria, pathogens and other contaminants [1] and the different techniques used to control

Manuscript received March 12, 2014; revised June 8, 2014.

Nawel Nedjah is with Preparatory School Science and Technology (EPST) Annaba, Algeria (e-mail: nedjah23nawel@gmail.com).

Oualid Hamdaoui and Nabila Laskri are with University Badji Mokhta Faculty of Engineering Sciences/Laboratory of Environmental Engineering Preparatory School Science and Technology (EPST), Annaba, Algeria (email: ohamdaoui@yahoo.fr, laskri_n@yahoo.fr). this pollution are:

- Physical processes based on physical separation of pollutants from wastewater,

- Chemical processes based on chemical reactions,

- Biological processes based on living organisms to break down waste materials [2].

While using these purification techniques, we have noticed that nutrients are not completely eliminated and the nutrient of major concern in protecting water quality is phosphorus [3], this latter and after the work of Riemann et al (1992) represents the limiting factor for eutrophication [4]. Situated in wastewater, phosphorus can pass through the sewage system without being properly treated; it is therefore released into rivers, causing the undesirable growth of algae and other pests that may contribute to eutrophication of the receiving water [5].

Domestic sewage is the main source of phosphorus discharges. This item appears in the inorganic and organic forms that are eventually converted into inorganic forms The forms of phosphorus are usually measured total phosphorus (TP), total dissolved phosphorus (TDP) and inorganic orthophosphate $\left(\mathrm{PO}_{4}{ }^{3-}\right)$ [2].

The process by chemical precipitation is the method most used to remove phosphorus from wastewater; otherwise we used three commonly used coagulants in water treatment [6]:

- Ferric chloride: $\mathrm{FeCl}_{3}$;

- Aluminum sulfate: $\mathrm{Al}_{2}\left(\mathrm{SO}_{4}\right)_{3}$;

- Lime: $\mathrm{Ca}(\mathrm{OH})_{2}$.

The use of chemicals in the treatment of urban waste water has increased with the degree of pollution mainly due to the disposal system sewage insufficiently pretreated industrial and mixed in the pipes of municipal wastewater [7].

Today, chemicals are used specifically for the removal of phosphorus and nitrogen.

The interest in the use of coagulants has increased due to the following reasons [4]:

- The methods for laboratory monitoring of coagulation have been improved.

- Modern methods for controlling chemical processes are more effective.

- The chemicals used have lower prices.

- The physico-chemical properties using coagulants and flocculants; makes water treatment very effective but produces more sludge [8].

From the perspective of the implementation of the coagulation-flocculation, two parameters are important:

1) The quantities of reagents to be added; 
2) The agitation speed of the reaction.

These parameters are determined by several tests on samples in the laboratory and this according to the nature of the wastewater to be treated.

The other existing wastewater treatment is biological treatment. On one hand, this kind of treatment involves mechanisms of sedimentation of settle able solids, and on the other hand, it makes use of the biological activity of microorganisms. They can be classified into two categories [9]:

- Intensive biological systems: they are conventional treatment systems that occupy less space and consume energy. In addition, their installation and operation costs are quite high. We distinguish treatment systems using activated sludge, trickling filters, rotating biological ... etc [10].

- Extensive biological systems: they are the lagoons: they are based on the phenomena of natural self-purification; they do not require any energy but require large areas and long periods of wastewater. From an economic standpoint, they are less expensive [11].

\section{MATERIELS ET AND METHODS}

\section{A. Campaigns Sampling}

Samples of wastewater were collected in June 2007 (summer) a lift station in the city of Annaba (Lift Station to Station). Samples were collected in polyethylene bottles and stored in damp and darkness, they have been able to direct of physico-chemical parameters (temperature, $\mathrm{pH}, \mathrm{COD}$ and $\mathrm{P})$. The measurement of phosphorus is done using the method of ammonium molybdate at $380 \mathrm{~nm}$ [12].

The raw water presents the physicochemical parameters following:

- $\mathrm{pH}=7.12$;

- $\quad$ Turb = 17.4 NTU;

- $\mathrm{COD}=50.928 \mathrm{mg} / \mathrm{l}$;

- $\mathrm{P}=0.009 \mathrm{mg} / \mathrm{l}$.

This wastewater has been the substrate of choice for all tests to optimize coagulation-flocculation.

1) Experiment $\mathrm{N}^{\circ} 1$ : Find the optimal dose of aluminum sulfate, indicated in Table I.

Operating conditions:

- Stirring speed: 200Tr/min;

- Stirring time: $15 \mathrm{~min}$.

TABLE I: OPTIMIZATION OF THE OPTIMAL DOSE AND EFFECTIVE

\begin{tabular}{|l|l|l|l|l|l|l|l|}
\hline $\begin{array}{l}\text { Dose } \\
(\mathrm{mg} / \mathrm{l})\end{array}$ & 30 & 80 & 100 & 150 & 200 & 300 & 350 \\
\hline $\begin{array}{l}\% \\
\text { Removal } \\
\text { of } \\
\text { phosphorus }\end{array}$ & 0 & 0 & 0 & 77.85 & 77.85 & 55.51 & 0 \\
\hline $\begin{array}{l}\text { Turbidity } \\
\text { (NTU) }\end{array}$ & 6.96 & 4.92 & 3.85 & 2.82 & 2.08 & 13.3 & 18.7 \\
\hline $\mathrm{pH}$ & 7.21 & 7.22 & 6.94 & 6.66 & 6.5 & 6.2 & 5.33 \\
\hline
\end{tabular}

According to the values shown in Table I, we see clearly that when adding a dose between $150 \mathrm{mg} / \mathrm{l}$ and $200 \mathrm{mg} / \mathrm{l}$ of aluminum sulfate, the waste water presents the lowest turbidity and $\mathrm{pH}$ as well as, especially good phosphorus removal efficiency.

Experimentally, we observe following the tests in the laboratory, that the waste water after the addition of the mentioned dose in Fig. 1 presents the weakest concentration and the waste water turns clearer.

The removal efficiency of parameters criteria of pollution are shown in Fig. 2.

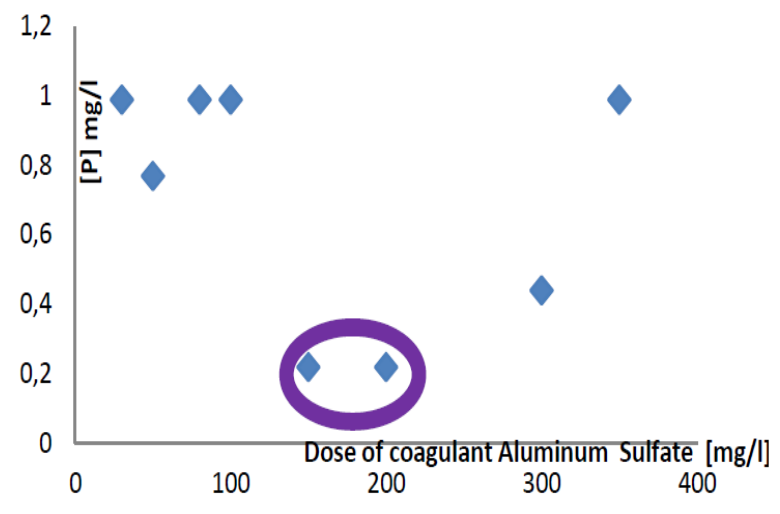

Fig. 1. Finding the optimal dose of aluminum sulfate as a function of phosphorus concentration from wastewater.

From Fig. 2 it is clear that the aluminum sulfate optimum dose of is between 100 and $200 \mathrm{mg} / 1$, the dose eliminates phosphorus to a very low value of $0.2 \mathrm{mg} / 1$, c is the lowest value.

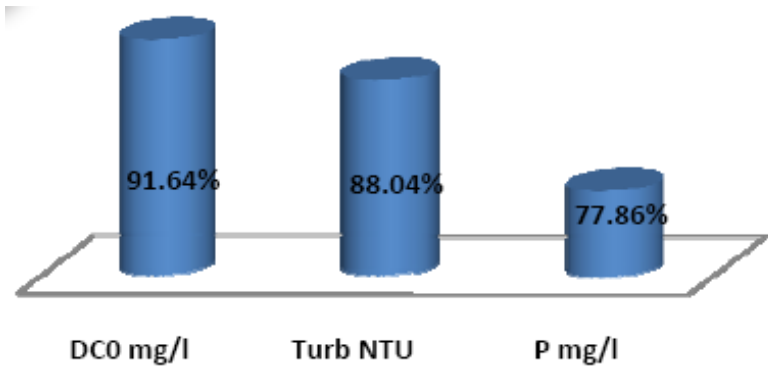

Fig. 2. Performance evaluation of chemical treatment by aluminum sulfate.

The optimal dose gives an excellent DCO removal of $91.64 \%$ and Phosphorus removal of $77.86 \%$.

2) Experiment $\mathrm{N}^{\circ} 2$ : Find the optimal dose of ferric chloride, indicated in Table II.

Operating conditions:

- $\quad$ Stirring speed: $200 \mathrm{rpm}$;

- Stirring time: $15 \mathrm{~min}$.

TABLE II: OPTIMIZATION OF THE OPTIMAL DOSE AND EFFECTIVE FERRIC

\begin{tabular}{|l|l|l|l|l|l|}
\hline Dose (mg/l) & 20 & 100 & 150 & 200 & 300 \\
\hline $\begin{array}{l}\% \quad \text { Removal } \\
\text { of } \\
\text { phosphorus }\end{array}$ & 55.51 & 66.63 & 66.63 & 88.87 & 33.27 \\
\hline $\begin{array}{l}\text { Turbidity } \\
\text { (NTU) }\end{array}$ & 12.8 & 5.93 & 2.04 & 1.68 & 2.45 \\
\hline pH & 6.96 & 6.58 & 6.45 & 6.29 & 5.95 \\
\hline
\end{tabular}

According to the values shown in Table II, we see clearly that when adding a dose $200 \mathrm{mg} / \mathrm{l}$ of ferric chloride, the waste water presents the lowest turbidity and $\mathrm{pH}$ as well as, especially good phosphorus removal efficiency. 


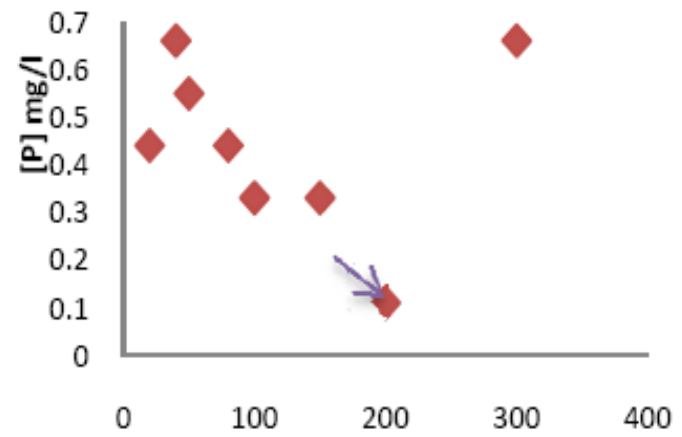

Dose of coagulant ferric chloride $[\mathrm{mg} / \mathrm{l}]$

Fig. 3. Finding the optimal dose of ferric chloride of phosphorus concentration from wastewater.

From Fig. 3 it is clear that the aluminum sulfate optimum dose of is $200 \mathrm{mg} / 1$, the dose eliminates phosphorus to a very low value of $0.1 \mathrm{mg} / \mathrm{l}, \mathrm{c}$ is the lowest value.

In the case of ferric chloride, the optimal dose would be $200 \mathrm{mg} / \mathrm{l}$ for decreasing the concentration of phosphorus from $0.989 \mathrm{mg} / \mathrm{l}$ to of $0.111 \mathrm{mg} / \mathrm{l}$, this dose is effective and it is shown in the curve of coagulant dose optimization indicated in Fig. 3. This chemical treatment has given a maximal phosphorus removal of $88.87 \%$ demonstrated in Fig. 4.

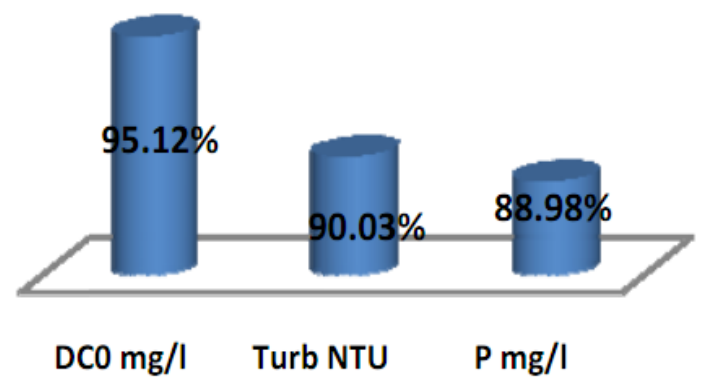

Fig. 4. Performance evaluation of chemical treatment by ferric chloride.

The optimal dose gives an excellent DCO removal of 95.12\% and Phosphorus removal of $88.98 \%$.

3) Experiment $\mathrm{N}^{\circ} 3$ : Finding the optimal dose of lime: Operating conditions, indicated in Table III.

- $\quad$ Stirring speed: $200 \mathrm{Tr} / \mathrm{min}$;

- Stirring time: $15 \mathrm{~min}$.

TABLE III: OPTIMIZATION OF THE OPTIMAL DOSE AND EFFECTIVE LIME

\begin{tabular}{|l|l|l|l|l|l|}
\hline Dose(mg/l) & 300 & 500 & 600 & 700 & 800 \\
\hline $\begin{array}{l}\text { Removal } \\
\text { of } \\
\text { phosphorus }\end{array}$ & 11.12 & 88.98 & 88.98 & 77.85 & 0 \\
\hline $\begin{array}{l}\text { Turbidity } \\
\text { (NTU) }\end{array}$ & 9.38 & 4.78 & 5.55 & 17.6 & 8.57 \\
\hline pH & 9.07 & 10.55 & 10.4 & 10.85 & 11.07 \\
\hline
\end{tabular}

The optimal dose found out in this test is between $500 \mathrm{mg} / \mathrm{l}$ and $600 \mathrm{mg} / \mathrm{l}$, Fig. 5 demonstrates clearly that this optimal dose presents the weakest phosphorus concentration and the highest removal efficiency. The removal efficiency of parameters criteria of pollution are shown in Fig. 6.

From Fig. 5 it is clear that the aluminum sulfate optimum dose of is between 400 and $600 \mathrm{mg} / 1$, the dose eliminates phosphorus to the lowest value.

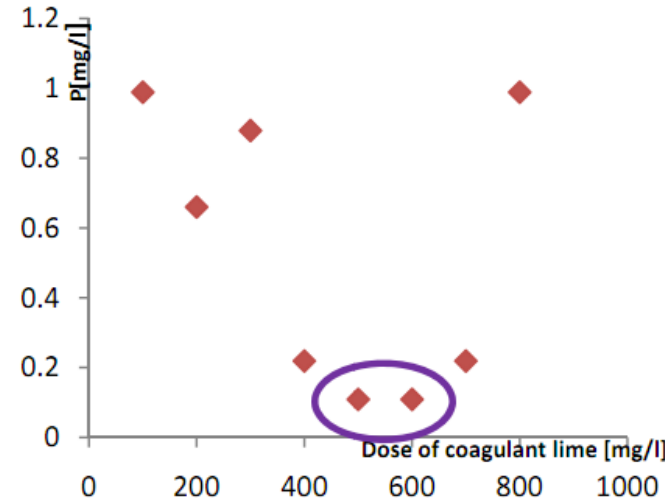

Fig. 5. Finding the dose optimal of lime of phosphorus concentration from wastewater.

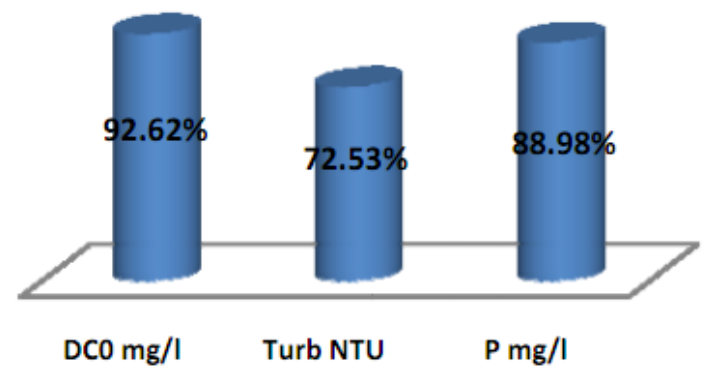

Fig. 6. Performance evaluation of chemical treatment by lime.

The optimal dose gives an excellent DCO removal of 92.62 \% and Phosphorus removal of $88.98 \%$.

\section{B. Performance of Chemical Treatment of Wastewater}

Following the use of the optimal dose found in the preceding experiments of each type of coagulant. The Table IV below shows the physico-chemical wastewater before and after chemical treatment.

TABLE IV: MEASUREMENT PARAMETERS CRITERIA OF POLLUTION BEFORE AND AFTER CHEMICAL TREATMENT

\begin{tabular}{|c|c|c|c|c|c|}
\hline & $\mathbf{P}(\mathrm{mg} / \mathrm{l}) .10$ & $\begin{array}{l}\text { DCO } \\
(\mathrm{mg} / \mathrm{l})\end{array}$ & $\mathbf{p H}$ & $\mathbf{T}^{\circ} \mathbf{C}$ & $\begin{array}{l}\text { Turb } \\
\text { (NTU) }\end{array}$ \\
\hline Raw sewage & 9.89 & 50.927 & 7.12 & 25 & 17.4 \\
\hline $\begin{array}{l}\text { Wastewater } \\
\text { after } \\
\text { treatment by } \\
\text { sulfate } \\
\text { aluminum }\end{array}$ & 2.19 & 5.009 & 6.5 & 25 & 2.08 \\
\hline $\begin{array}{l}\text { Wastewater } \\
\text { after } \\
\text { treatment by } \\
\text { chloride } \\
\text { ferric }\end{array}$ & 1.1 & 2.922 & 6.29 & 25 & 1.68 \\
\hline $\begin{array}{l}\text { Wastewater } \\
\text { after } \\
\text { treatment by } \\
\text { lime }\end{array}$ & 1.09 & 3.756 & 10.4 & 25 & 4.78 \\
\hline
\end{tabular}

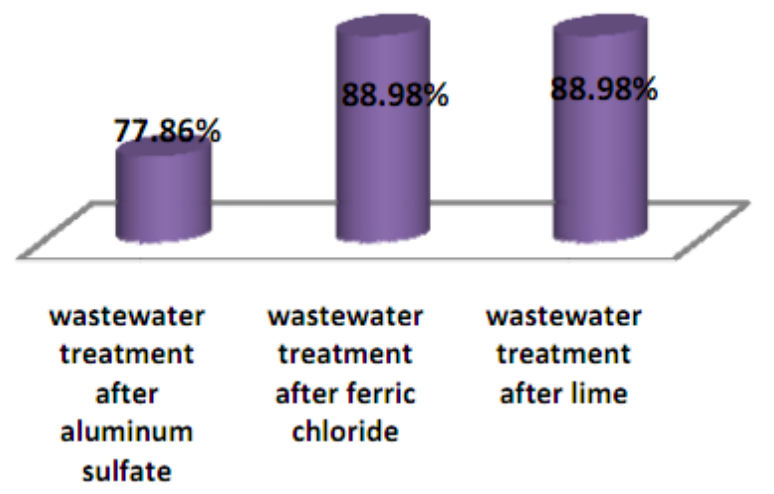

Fig. 7. Removal percentage of phosphorus. 
We also determined the removal efficiency of each coagulant by measuring turbidity, total phosphorus; Fig. 7, Fig. 8 demonstrates clearly the efficiency of the chemical treatment.

Lime and ferric chloride gave a very good phosphorus removal efficiency compared with aluminum sulfate.

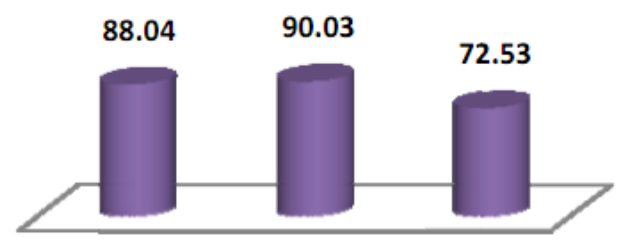

$$
\begin{gathered}
\text { wastewater wastewater wastewater } \\
\text { treatment treatment treatment } \\
\text { after after ferric after lime } \\
\text { aluminum chloride } \\
\text { sulfate }
\end{gathered}
$$

Fig. 8. Removal Percentage of turbidity from wastewater.

Ferric chloride gave a very good turbidity removal efficiency of $90.03 \%$ compared with other coagulants: aluminum sulfate, Lime.

\section{DISCUSSION}

The optimal dose of aluminum sulfate is $200 \mathrm{tr} / \mathrm{min}$ with a good phosphorus removal efficiency of $91 \%$

The optimal dose of ferric chloride is $200 \mathrm{tr} / \mathrm{min}$ with a good phosphorus removal efficiency of $89 \%$,

The optimal dose of lime is $500 \mathrm{tr} / \mathrm{min}$ with a good phosphorus removal efficiency of $89 \%$.

From this result, it is found that the three coagulants if used in wastewater treatment plant enable the reduction of phosphorus concentration in receiving milieu such as lakes and seas.

\section{CONCLUSION}

The physico-chemical removal of phosphorus in waste water by the use of selected inorganic salts (ferric chloride, aluminum sulfate and lime) can be effective in a treatment plant in order to reduce the concentration of this nutrient discharged into receiving waters et reduce their eutrofication.

In general, the choice of a method of treatment depends on several criteria not only the treatment efficiency but also the cost of the investment. In fact policy makers can't decide on the best approach without considering a number of factors mainly (economic, financial, environmental and socio-political techniques) such factors are vital for the achievement of acceptable and feasible solution [13].

\section{REFERENCES}

[1] Operation of municipal wastewater treatment plants, Management and Support Systems, Manual of practice, no. 11, vol. I, sixth Edition, WEF Press, 2008.

[2] The Lakes Handbook Volume 2, Lake Restoration and Rehabilitation, Black Well Publishing, 2005

[3] F. Edline, L'épuration Biologique Des Eaux, Tec \& doc Lavoisier éd, Paris, 1993.

[4] A. Stoddard, Municipal Wastewater Treatment-Evaluation Improvement in National Water Quality, John Wiley \& sons Inc, 2002.

[5] H. Roques, Fondement Théoriques du Traitement des Eaux, Tec \& doc Lavoisier éd, Paris, 1990.

[6] N. Milaude, "Le traitement des eaux usées des communes à forte population estivale," Eau L', L'industrie; les nuisances, no. 113, pp. 55-57, 1990.

[7] N. P. Cheremisinoff, Handbook of Water and Wastewater Treatment Technologies, Butterworth-Heinemann, 2002.

[8] T. Asano et al., Water Reuse-Issues, Technologies and Applications, Metcalf \& Edy Inc, 2007.

[9] G. Martin, L'épuration et le Traitement des Effluents (eau et Air), Ed TEC \& DOC, 1985.

[10] J. Rodier, Analyse de l'eau, 7ème édition Dunod, 1984

[11] René. Scriban, Biotechnologie, CEBEDOC, 1993.

[12] M. L. Gougnard and J. J. Sanglier, Biotechnologie: Principes et Méthodes, éd Doin, 1992.

[13] N. Kibi, J. L. Sasseville, J. M. Martel, and J. F. Blais, "Choix multicritere de procedes d'epuration des eaux usees municipales,' Revue des Sciences de L'eau, Journal of Water Science, vol. 13, no. 1 , pp. 21-38, 2000 .
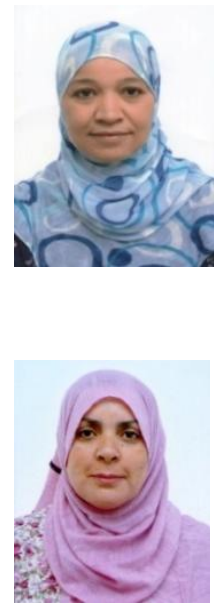

Algeria.

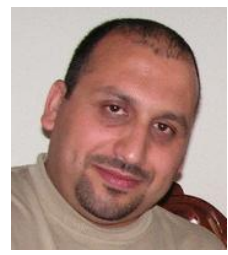

Oualid Hamdaoui graduated with his engineering degree at the Department of Process Engineering, University of Annaba and received the magister and $\mathrm{PhD}$ degrees at the same department in 1997 and 2004 respectively. He is working as a senior lecturer at the Process Engineering Department since 2005. He is a member of the Laboratory "Molecular Chemistry and Environment", University - SAVOIE, France, as well as a conference session chair and technical review committee 